\title{
What's New in Forest Research
}

Many foresters in Canada have little time or opportunity to keep abreast with the scientific literature in forestry. To help alleviate this problem, abstracts of relevant articles published in the Canadian Journal of Forest Research will appear in the Forestry Chronicle in the future insofar as space permits. Those following came from the December ' 83 issue of CJFR.

Carter, K.K., F.C. Cech, and D.H. DeHayes. 1983. Geographic variation in Prunus serotina. Can. J. For. Res. 13: 1025-1029.

In 1969, 1-year-old black cherry (Prunus serotina Ehrh.) seedlings from 21 to 33 provenances were planted at each of four locations in the northeastern United States. After 10 growing seasons, survival at each plantation was related to the latitude of the seed source. Differences in height among provenances were not correlated with the latitude of the seed source. Provenance $x$ plantation interaction for height was large, as were differences in mean height among plantations. Differences in leaf characteristics were associated with the location of the seed source, but the pattern of variation in stem form was random rather than regional.

En 1969, des semis d'un an de Prunus serotina Ehrh. de 21 à 33 provenances furent plantés dans quatre stations du nord-est des États-Unis. Après 10 saisons de croissance, la survie des plants à chacune des stations fut évaluée en relation avec la latitude de provenance des semences. Les différences en hauteur des plants de diverses provenances n'étaient pas corrélées avec la latitude des sources de semences. L'interaction provenance $X$ plantation pour la hauteur des plants était élevée, de même que les différences de hauteur moyenne entre les plantations. Les différences dans les caractères des feuilles étaient attribuables à l'origine des semences, mais le pattern de variation de forme de tige était aléatoire plutôt que régional.

Weetman, G.F., and D. Algar. 1983. Low-site class black spruce and jack pine nutrient removals after full-tree and tree-length logging. Can. J. For. Res. 13: 1030-1036.

An old, merchantable, low-site class black spruce (Picea mariana (Mill.) B.S.P.) stand growing on a Lithic Humo-Ferric Podzol overlying a granite bedrock, and a younger but merchantable low-site class jack pine (Pinus banksiana Lamb.) stand growing on a Ferro-Humic Podzol overlying a deep coarse sand near Baie Comeau, P.Q., were analysed for stand biomass and macronutrient contents of both stand and soil. The magnitude of the depletions of macronutrients from the site, in full-tree and tree-length methods of logging, are compared with their available and tota quantities in the soil. The range of values from the literature for nutrient inputs are presented and discussed in relation to logging losses. The results suggest that full-tree logging in the dry jack pine stand could cause a severe loss of potentially mineralizable $\mathrm{N}$ supply; $\mathrm{P}, \mathrm{K}$, and $\mathrm{Mg}$ deficiency problems owing to export are not apparent, but a Ca balance problem is apparent. The implication is that full-tree logging should be avoided on such sites.

Les auteurs ont mesuré la biomasse et les contenus en éléments majeurs des peuplements et des sols de deux stations forestières près de Baie-Comeau, Québec. L'une des stations est colonisée par Picea mariana (Mill.) B.S.P. en peuplement âgé et marchand, sur podzol humo-ferrique lithique reposant sur assise granitique; l'autre station est colonisée par Pinus banksiana Lamb., en peuplement jeune et marchand, associé à un podzol ferro-humique sur sable grossier profond. L'article compare l'importance des déplétions d'éléments pour deux méthodes d'exploitation: par arbres entiers et par fûts entiers, en regard des réserves d'éléments du sol sous formes assimilable et totale. L'éventail des données publiées sur les inputs d'éléments est présenté et discuté en regard des exportations occasionnées par l'exploitation. Les résultats suggèrent que l'exploitation par arbres entiers dans le peuplement de pin sur station sèche peut occasionner une perte sévère de $\mathrm{N}$ et constituer des problèmes pour $\mathrm{Ca}$; l'impact de déplétion de $\mathrm{P}, \mathrm{K}$ et $\mathrm{Mg}$ n'est pas apparent. L'exploitation par arbres entiers devrait être évitée sur de tels sites.
McShane, M.C., D.W. Carlile, and W.T. Hinds. 1983. The effect of collector size on forest litter-fall collection and analysis. Can J. For. Res. 13: 1037-1042

Litter fall is commonly collected for a variety of ecological studies. This study was designed to test the effect of collector size on the precision of forest litter-fall estimates and on the time involved in laboratory sample sorting. Collectors varied in size from 0.010 to $0.933 \mathrm{~m}^{2}$ and were physically nested, the smaller units within larger units. Ten of these collector combinations were randomly placed on a 1-ha plot in a Douglas-fir / western hemlock (Pseudotsuga menziesii (Mirb.) Franco/Tsuga heterophylla (Raf.) Sarg.) stand in H.J. Andrews Experimental Forest. Collections were made monthly and records were kept of the time required to sort the litter into needles. epiphytes, and miscellaneous categories. Based on a definition of precision as $\pm 10 \%$ of the mean, $90 \%$ of the time, results indicate (i) that the cost of obtaining precise estimates of needle fall decreases with decreasing collector size to $0.010 \mathrm{~m}^{2}$, (ii) that collectors of any size can be used to obtain estimates of total litter fall if the number of collectors required to obtain precise results is determined, and (iii) that precise estimates of epiphyte biomass require large numbers of samplers and are not cost effective.

La cueillette de litière est une opération courante pour des études écologiques diverses. La présente étude fut entreprise dans le but de déterminer l'effet des dimensions des collecteurs sur la précision des estimations de litière et sur le temps consacré en laboratoire à la séparation des constituants. A cette fin, on a disposé une série de collecteurs $\left(0,010\right.$ à $\left.0,933 \mathrm{~m}^{2}\right)$ les uns dans les autres en batterie concentrique. Dix de ces batteries furent placées aléatoirement dans une placette de 1 ha sous couvert de Pseudotsuga menziesii (Mirb.) Franco et Tsuga heterophylla (Raf.) Sarg., dans la Forêt Expérimentale H.J. Andrews. Les cueillettes étaient mensuelles et on a noté le temps requis pour la séparation des constituants (aiguilles, épiphytes et autres catégories). Pour une précision définie comme étant $\pm 10 \%$ de la moyenne à $90 \%$ du temps, les résultats montrent que: (i) le coût nécessaire à l'obtention d'estimations précises de la litière d'aiguilles décroît avec la diminution des dimensions des collecteurs jusqu'à $0,010 \mathrm{~m}^{2}$; (ii) des collecteurs de toutes dimensions peuvent être utilisés pour des estimations de la litière totale si le nombre de collecteurs requis pour obtenir une précision donnée est prédéterminé; (iii) les estimations précises de biomasse d'épiphytes requièrent un grand nombre de collecteurs et sont coûteuses.

Winkler, R.D., and R.L. Rothwell. 1983. Biogeoclimatic classification system for hydrologic interpretations. Can. J. For. Res. 13: $1043-1050$.

The purpose of this study was to assess the utility of the biogeoclimatic land-classification system for hydrologic interpretations. It was hypothesized that hydrologic recharge and discharge areas could be identified in a watershed using biogeoclimatic survey data. An intensive biogeoclimatic survey was conducted in Tri Creeks Experimental Watershed, which is located $70 \mathrm{~km}$ southwest of Edson, Alberta. Plant associations identified by the survey were evaluated as either recharge or discharge areas based on species composition, slope position, relative water yield, soil-water storage, and peak-flow estimates based on a modified form of the rational equation. The biogeoclimatic survey identified two distinct plant associations. Each plant association was characterized by four to six indicator species. Genera for plant association A included Geum, Salix, and Betula, and those for plant association B included Arnica, Cornus, and Vaccinium. Plant association $\mathrm{A}$ was considered representative of discharge areas because of its location on lower slopes adjacent to stream chan- 
nels, and the presence of plant species indicative of wet riparian habitats. Association B was judged a recharge area because of its location on upper slopes and the presence of plant species indicative of drier habitats. Simple water-balance calculations for each plant association further supported these interpretations. The greater relative water yield and soil-water content throughout the growing season for association A over association B were judged a reflection of its location in a discharge area. The prediction of peak flows, using the areal extent of association $A$ in the rational equation, also supported its identification as a discharge area The precision of prediction was low with estimated values exceeding actual values by $1-4$ times. However, moderate to high levels of correlation between estimated peaks and actual peaks were observed for late-summer storms, and judged to demonstrate the importance of association A as a discharge area for storm flow.

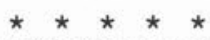

Le but de cette étude a été d'évaluer l'utilité de la classification biogéoclimatique du territoire pour l'interprétation hydrologique. On a émis l'hypothèse que les données biogéoclimatiques pourraient permettre l'identification des surfaces d'alimentation et de résurgence d'un bassin hydrologique. À cette fin, une étude biogéoclimatique intensive a été réalisée dans le Bassin expérimental Tri Creeks, situé à $70 \mathrm{~km}$ au sud-ouest de Edson, Alberta. Les associations végétales identifiées ont été évaluées en terme de surfaces d'alimentation ou de résurgence, sur la base de leur composition floristique, de leur position sur la pente, de leur débit relatif, de leur capacité de rétention en eau et de l'estimation du débit de pointe. L'étude biogéoclimatique a permis d'identifier deux associations végétales distinctes. Chacun d'elles a été caractérisée par quatre à six espèces indicatrices. Les genres de l'association A comprenaient Geum, Salix et Betula, et ceux de l'association B Arnica, Cornus et Vaccinium. A cause de sa position au bas des pentes près du lit des cours d'eau, et de la présence de plantes indicatrices des habitats rivererains humides, l'association $\mathrm{A}$ a été considérée comme représentative des surfaces de résurgence. Par contre, l'association $\mathrm{B}$ a été considérée comme aire d'alimentation à cause de sa position dans la partie supérieure de la pente et de la présence des plantes indicatrices des habitats plus secs. Le calcul ultérieur du bilan hydrologique de chaque association a confirmé cette interprétation. La capacité de rétention relative et la teneur en eau plus élevée durant la saison de végétation, dans le cas de l'association A par rapport à l'association $\mathrm{B}$, ont été considérées comme réflétant sa position dans la surface de résurgence. La précision de prédiction a été faible dans le cas des valeurs estimées qui étaient de 1 à 4 fois plus grandes que les valeurs actuelles. Toutefois, une corrélation moyenne à forte a été observée entre les valeurs estimées et les valeurs observées du débit de pointe après les orages d'été.

Cecich, R.A. 1983. Flowering in a jack pine seedling seed orchard increased by spraying with gibberellin $A_{4 / 7}$. Can. J. For. Res. 13: 1056-1062

Jack Pine (Pinus banksiana Lamb.), in a 3-year-old orchard established with accelerated-growth seedlings, were sprayed with gibberellin $\mathrm{A}_{4 / 7}\left(\mathrm{GA}_{4 / 7}\right)$ in an Aromox-ethanol solution during the 1981 growing season. Seven treatment periods were evaluated: the entire growing season, shoot elongation, bud development, early (first half) and late (second half) shoot elongation, and early and late bud development. Three concentrations of GA $\left(200,400\right.$, and $\left.600 \mathrm{mg} \cdot \mathrm{L}^{-1}\right)$ were applied in all combinations with treatment periods. Three treatments increased female flowering: 400 and $600 \mathrm{mg} \cdot \mathrm{L}^{-1} \mathrm{GA}_{4 / 7}$ sprayed the entire growing season and $600 \mathrm{mg} \cdot \mathrm{L}^{-1}$ sprayed during bud development. The number of pollen clusters was increased by spraying 400 and $600 \mathrm{mg} \cdot \mathrm{L}^{-1}$ $\mathrm{GA}_{47}$ during any treatment period except early shoot elongation and late bud development or during shoot elongation $\left(400 \mathrm{mg} \cdot \mathrm{L}^{-1}\right.$ only). The $200 \mathrm{mg} \cdot \mathrm{L}^{-1} \mathrm{GA}_{4 / 7}$ increased pollen clusters only if sprayed during early bud development or the entire growing season. The percentage of trees bearing pollen increased with all concentrations of $\mathrm{GA}_{4}$. The 1982 shoot growth of trees sprayed in 1981 during shoot elongation or the entire growing season (all $\mathrm{GA}_{4}$ levels pooled) was significantly less than control-tree growth or that of trees in the other treatment periods. The best treatment for increasing both male and female strobili was $600 \mathrm{mg} \cdot \mathrm{L}^{-1} \mathrm{GA}_{4 / 7}$ sprayed during bud development.

Des pins gris (Pinus banksiana Lamb.) âgés de 3 ans cultivés dans un verger peuplé de semis à croissance rapide furent arrosés pendant la saison de croissance 1981 de gibberelline $A_{4 / 7}\left(G_{4 / 7}\right)$ solubilisée dans un mélange Aromox-éthanol. Sept durées de traitement sont évaluées: pendant toute la saison de croissance, pendant toute la durée de l'élongation caulinaire, ou pendant la première ou la deuxième moitié de l'élongation caulinaire, pendant toute la durée du développement des bourgeons ou pendant la première ou la deuxième moitié du développement des bourgeons. Trois concentrations de $\mathrm{GA}_{4 / 7}(200,400$ et $600 \mathrm{mg} \cdot \mathrm{L}^{-1}$ ) sont appliquées en combinaison avec toutes les sept durées de traitements. Trois traitements augmentent le développement des fleurs femelles: 400 et $600 \mathrm{mg} \cdot \mathrm{L}^{-1} \mathrm{de} \mathrm{GA}_{4 / 7}$ appliqués pendant toute la saison de croissance et $600 \mathrm{mg} \cdot \mathrm{L}^{-1}$ pendant le développement des bourgeons. Le nombre de sacs polliniques est augmenté par l'application de 400 ou $600 \mathrm{mg} \cdot \mathrm{L}^{-1} \mathrm{GA}_{4,7}$ pendant n'importe quelle durée de traitement sauf pendant la première partie de l'élongation caulinaire, la deuxième partie du développement des bourgeons ou par $400 \mathrm{mg} \cdot \mathrm{L}^{-1}$ appliquée pendant l'élongation caulinaire. L'application de $200 \mathrm{mg} \cdot \mathrm{L}^{-1}$ de $\mathrm{GA}_{4 / 7}$ n'augmente le nombre de sacs polliniques que pendant la première partie du développement des bourgeons ou pendant toute la saison de croissance. La proportion d'arbres produisant du pollen augmente avec l'application de n'importe laquelle des concentrations de GA $\mathrm{G}_{47}$ testées. La croissance caulinaire subséquente (saison 1982) des arbres arrosés pendant l'élongation caulinaire ou pendant toute la saison de croissance (toutes des concentrations de $\mathrm{GA}_{4 / 7}$ combinées) est significativement diminuée par rapport aux temoins ou aux arbres des autres traitements. Le meilleur traitement pour augmenter la production de cônes (strobiles) mâles et femelles est $600 \mathrm{mg} \cdot \mathrm{L}^{-1} \mathrm{de} \mathrm{GA}_{4 / 7}$ appliqués pendant le développement des bourgeons.

Morton, R.T., S.J. Titus, and P.H. Crown. 1983. Natural-color and color-infrared photography for the identification of foreststand density, height, and species composition. Can. J. For. Res. 13: 1063-1067

Natural-color and color-infrared aerial photography at scales of $1: 30000,1: 50000$, and 1:70 000 were evaluated for the interpretation of forest-stand density, height, and species class, for test areas in the boreal and foothills regions of Alberta. Accuracy was assessed by comparing photo interpreter identification to field measurements. When averaged over all scales, color film types did not differ in accuracy. Scale affected identification accuracy for density and species class. The 1:70 000 scale was most accurate for estimating density and least accurate for species class. Scale did not affect identification accuracy for $6-m$ height classes. Interpreter inventory experience and colordiscrimination ability both affected accuracy for species class, but not density or height. Standard 1:15 000 scale black and white photography was not significantly more accurate than any of the other film-scale combinations for identification of density, height, or species class.

Les auteurs ont utilisé la photographie aérienne en couleurs naturelles et en couleur infrarouge aux échelles de 1:30 000 $1: 50000$ et 1:70 000 pour l'interprétation de la densité des peuplements forestiers, la hauteur des arbres et la classe d'espèces, dans des aires de référence en région boréale et en région des contreforts des Rocheuses en Alberta. La précision fut mesurée en comparant l'identification faite par le photo-interprète avec des mesures au champ. L'échelle des photos a influencé la justesse d'identification de la densité et de la classe d'espèces. L'échelle $1: 70000$ s'est avérée la plus précise pour l'estimation de la densité et la moins précise pour la classe d'espèces. L'échelle n'a pas affecté la précision d'identification pour des classes de hauteur de $6 \mathrm{~m}$. L'expérience de l'interprète dans le domaine des inventaires forestiers et son habileté à discriminer les couleurs ont affecté la justesse des classes d'espèces, mais non la densité ou la hauteur. La photographie standard en blanc et noir, à 
l'échelle de 1:15000, ne s'est pas avérée plus précise que toute autre combinaison film-échelle pour l'identification de la densité, de la hauteur, ou de la classe d'espèces.

Wingfield, M.J., and R.A. Blanchette. 1983. The pine-wood nematode, Bursaphelenchus xylophilus, in Minnesota and Wisconsin: insect associates and transmission studies. Can. J. For. Res. 13: 1068-1076.

The pine-wood nematode, Bursaphelenchus xylophilus (Steiner and Buhrer), was most commonly extracted from Cerambycidae emerging from nematode-infested pines in Minnesota and Wisconsin during 1981 and 1982. The greatest number of nematodes were extracted from Monochamus scutellatus (Say) and Monochamus carolinenis (Olivier). Low numbers of $B$. xylophilus were found in some buprestids but no nematodes were found in the curulionid and scolytid beetles examined. Two species of Cerambycidae, Monochamus marmorator (Kiby.) and $M$. scutellatus were associated with $B$. xylophilus from balsam fir in Minnesota. Bursaphelenchus xylophilus from insects associated with balsam fir were morphologically different from insects associated with pine. Dauer larvae of $B$. xylophilus were concentrated in the thoracic segments of $M$. scutellatus and Monochamus mutator (Lec.) examined. Bursaphelenchus xylophilus was transmitted to twigs during maturation feeding and to logs during oviposition by $M$. carolinensis, $M$. mutator, and $M$. scutellatus.

$$
\text { * * * * * }
$$

Le Bursaphelenchus xylophilus (Steiner et Buhrer), un nématode du bois de pin fut communément extrait de cérambyx émergeant de pins infestés de nématodes au Minnesota et au Wisconsin durant les années 1981 et 1982. Le plus grand nombre de nématodes fut extrait des Monochamus scutellatus (Say) et $M$. carolinensis (Olivier). Un petit nombre de nématodes fut trouvé chez certains buprestes mais aucun ne fut trouvé chez les charançons et les scolytes examinés. Au Minnesota, le $M$. marmorator (Kiby.) et le M. scutellatus, provenant de bois de sapin étaient associés au $B$. xylophilus. La morphologie du nématode diffère selon qu'il est associé à des insectes venant du sapin ou du pin. Chez les spécimens de $M$. scutellatus et $M$. mutator (Lec.) examinés, on trouvé des masses de larves "dauer" (en latence) du nématode dans les segments thoraciques. Le transfert du $B$. xylophilus aux rameaux et aux billes se faisait, respectivement, durant l'alimentation de maturation et durant la ponte par les $M$. carolinensis, M. mutator et $M$. scutellatus.

Fitzgerald, J.W., J.T. Ash, T.C. Strickland, and W.T. Swank. 1983. Formation of organic sulfur in forest soils: a biologically mediated process. Can. J. For. Res. 13: 1077-1082.

The ability of soils from hardwood, clear-cut, and pine forests to incorporate sulfur from added inorganic sulfate into saltextractable (adsorbed) and nonsalt-extractable forms was investigated. At least $65 \%$ of the added sulfate was adsorbed while $8-27 \%$ of the sulfate added was recovered only after treatment of salt-extracted samples with acid and base (nonsalt-extractable sulfur). The incorporation of sulfur into this latter fraction was dependent upon incubation time, temperature, and depth and exhibited both spatial as well as seasonal variation in samples taken along a transect of one of the watersheds. Sulfur incorporation into the nonsalt-extractable fraction was inhibited $75-87 \%$ by sodium azide, $62-84 \%$ by erythromycin, and $41-68 \%$ by candicidin suggesting that the process is mediated by bacteria and fungi. Data on factors influencing sulfur incorporation suggest that sulfate was incorporated into organic matter as a covalent linkage and released after rupture of this linkage during acid and base treatment. The observations that ${ }^{35} \mathrm{~S}$ incorporation was inhibited $93-99 \%$ by unlabelled sulfate and stimulated $21-65 \%$ by increased carbon availability are consistent with this suggestion.

Les auteurs ont étudié l'adsorption du soufre ajouté sous forme de sulfate inorganique à des sols de forêts feuillues, de parterres de coupe et de forêts de pin. Au moins $65 \%$ du sulfate ajouté fut adsorbé, tandis que 8-27\% fut récupéré après traitement des échantillons avec un acide et une base (soufre extractible sous forme autre qu'un sel). L'incorporation du soufre dans cette dernière fraction dépend du temps d'incubation, de la température et la profondeur, et présente des variations spatiales et saisonnières pour des échantillons prélevés le long d'un transect d'un des bassins. L'incorporation du soufre dans la fraction extractible sous forme autre qu'un sel est inhibée à $75-87 \%$ par l'azide de sodium, à $62-84 \%$ par l'érythromycine et à $41-68 \%$ par la candicidine, suggérant un processus biologique. Les données relatives aux facteurs qui influencent l'incorporation du soufre suggèrent que le sulfate est incorporé sous forme organique par un lien covalent et est libéré par rupture de ce lien par traitement avec un acide et une base. Les observations à l'effet que l'incorporation de 35 S est inhibée à 93-99\% par un sulfate non marqué et stimulé à $21-65 \%$ avec l'augmentation de la disponibilité de la source de carbone sont à l'appui de cette suggestion.

Rice, P.M., R.A. Boldi, C.E. Carlson, P.C. Tourangeau, and C.C. Gordon. 1983. Sensitivity of Pinus ponderosa foliage to airborne phytotoxins: use in biomonitoring. Can. J. For. Res. 13: $1083-1091$

Pinus ponderosa Laws. foliage from a relatively nonpolluted area $\left(\mathrm{SO}_{2} \leqslant 5.2 \mu \mathrm{g} / \mathrm{m}^{3}\right.$, annual average) was compared with foliage from a more polluted area $\left(75 \mu \mathrm{g} / \mathrm{m}^{3}\right.$, annual maximum average) over a 6 -year period. Total sulfur and fluoride concentrations, frequencies of basal needle injury and healthy needles, and percent needle surface area affected (chlorotic and necrotic) classified as tip necrosis, mottle, and total necrosis were substantially higher at the polluted site and were judged to be sensitive characteristics. Two years following study inception, the first 700 $\mathrm{MW}$ of a planned 2100-MW coal-fired electric generating facility began operating in the nonpolluted area. No consistent changes were noted in the foliar characteristics measured in the nonpolluted area since power-plant start-up, and it is concluded that the facility's emissions did not measurably impact the pine ecosystem during the yearly years of operation.

Les auteurs ont comparé les caractères du feuillage de Pinus ponderosa Laws. provenant de régions relativement non polluées $\left(\mathrm{SO}_{2} \leqslant 5,2 \mu \mathrm{g} / \mathrm{m}^{3}\right.$, moyenne annuelle) et de régions davantage polluées $\left(75 \mu \mathrm{g} / \mathrm{m}^{3}\right.$, moyenne maximum annuelle). Les concentrations en soufre et en fluor des aiguilles, la fréquence d'aiguilles avariées et le pourcentage de la surface des aiguilles affectées par une chlorose ou une nécrose furent appréciablement plus élevés dans la région polluée et se sont avérés être des caractéristiques sensibles. Deux ans après le début de l'étude, on a mis en opération (700 MW des $2100 \mathrm{MW}$ projetés) une usine d'électricité produite par combustion du charbon dans la région non polluée. On n'a pas décelé de changements consistants des caractéristiques foliaires dans cette région depuis la mise en opération de l'usine, ce qui indique que l'impact sur l'écosystème est négligeable au cours des premières années d'opération.

Chapin, F.S., III, P.R. Tryon, and K. Van Cleve. 1983. Influence of phosphorus on growth and biomass distribution of Alaskan taiga tree seedlings. Can. J. For. Res. 13: 1092-1098.

Seedlings of six Alaskan taiga tree species and one tall shrub were grown in sand at three phosphate levels. There was a positive correlation between the growth rate of a species at the high-phosphate level in sand culture and its productivity in the natural environment. Poplar (Populus balsamifera L.), which had highest growth rate under high phosphate, was most sensitive to reduction in phosphate supply, followed by birch (Betula papyrifera (Reg.) Fern. and Raup) and aspen (Populus tremuloides Michx.), whereas growth of conifers (larch (Larix laricina (Du Roi) K. Koch), white spruce (Picea glauca (Moench) Voss), and black spruce (P. mariana (Mill.) B.S.P.)) from late successional sites was slow and unaffected by phosphate supply. Similarly, when birch and white spruce seedlings were transplanted into natural forest stands, the maximum growth rate of birch was greater than that of white spruce, but birch growth was curtailed more by unfavorable conditions than was that of white spruce. We conclude that a slow growth rate reduces nutrient requirement and therefore minimizes nutrient stress on infertile sites, whereas a rapid growth enables nutrient-demanding species to dominate fertile sites. 
Les auteurs ont mesuré l'influence du phosphore sur la croissance et la distribution de la biomasse de semis de six espèces d'arbres et d'une espèce d'arbuste de la taïga en Alaska. Les semis furent cultivés sur sable à trois niveaux de phosphate. On a mis en évidence l'existence d'une corrélation positive entre le taux de croissance d'une espèce au plus fort niveau de phosphate en culture sur sable et sa productivité en milieu naturel. Populus balsamifera L., qui avait le plus fort taux de croissance en milieu riche en phosphate, s'est avéré être l'espèce la plus sensible à la réduction du niveau de phosphate, suivi de Betula papyrifera (Reg.) Fern. et Raup et de Populus tremuloides Michx. Par contre, la croissance des conifères (Larix laricina (Du Roi) $\mathrm{K}$ Koch, Picea glauca (Moench) Voss et Picea mariana (Mill) (B.S.P.) était lente et elle ne fut pas affectée par le niveau de phosphate. De même, lorsque les semis de bouleau et d'épinette blanche furent transplantés en milieu naturel, le taux de croissance maximum du bouleau était plus élevé que celui de l'épinette blanche, mais la croissance du bouleau fut diminuée par les conditions défavorables de station, plus encore que ne le fut celle de l'épinette blanche. On conclut que le faible niveau de croissance diminue les besoins en éléments et conséquemment minimise le stress nutritionnel sur les sites pauvres, alors que la croissance rapide permet aux espèces exigeantes de dominer les sites riches.

Ekwebelam, S.A., and C.P.P. Reid. 1983. Effect of light, nitrogen fertilization, and mycorrhizal fungi on growth and photosynthesis of lodgepole pine seedlings. Can. J. For. Res. 13: 1099-1106.

Seedlings of lodgepole pine (Pinus contorta Dougl.) were grown for 10 weeks without ectomycorrhizae in the greenhouse at three levels of irradiance (low, medium, and high) and ammonium nitrate $(3,62$, and $248 \mathrm{ppm} \mathrm{N})$. At 10 weeks, inoculation with either Pisolithus tinctorius (Pers.) Coker and Couch or Suillus granulatus (L. ex Fr.) O. Kuntze was superimposed on light and nitrogen treatments, and the seedlings were grown for an additional 6 weeks. Mycorrhiza formation increased with increase in irradiance, while fertilization with $62 \mathrm{ppm} \mathrm{N}$ resulted in greater mycorrhiza formation than either 3 or $248 \mathrm{ppm} \mathrm{N}$. Further, inoculated plants had significantly greater biomass and took up more phosphorus than nonmycorrhizal seedlings. Inoculation with P. tinctorius and $S$. granulatus resulted in photosynthetic rates of 1.87 and $1.85 \mathrm{mg} \mathrm{CO} \mathrm{CO}_{2} \cdot \mathrm{dm}^{-2} \cdot \mathrm{h}^{-1}$, respectively, significantly greater than nonmycorrhizal plants $\left(1.41 \mathrm{mg} \mathrm{CO} \mathrm{CO}_{2} \cdot \mathrm{dm}^{-2} \cdot \mathrm{h}^{-1}\right)$. Although the increase in growth of the mycorrhizal seedlings was associated with increased photosynthesis, the magnitude of this response depended on specific combinations of irradiance and nitrogen fertilization. These results emphasize the importance of interactions among irradiance, nitrogen fertilization, and mycorrhiza development in the growth of containerized seedlings.

$$
\text { * * * * * }
$$

Des semis de Pinus contorta Dougl. ont été cultivés en serre durant 10 semaines, en l'absence de mycorhizes, à trois niveaux d'irradiance (faible, moyen, élevé) et de nitrate d'ammonium ( 3 , $62,248 \mathrm{ppm} \mathrm{N}$ ). Après 10 semaines, l'inoculation avec soit $P$ isolithus tinctorius (Pers.) Coker \& Couch, ou soit Suillus granulatus (L. ex Fr.) O. Kuntze, fut surajoutée aux traitements de lumière et d'azote, et les semis furent cultivés pour une période additionnelle de 6 semaines. La formation de mycorhizes a augmenté avec l'augmentation de l'irradiance, alors que la fertilisation à $62 \mathrm{ppm} \mathrm{N}$ a favorisé davantage la mycorhization que les traitements à 3 ou à $248 \mathrm{ppm} \mathrm{N}$. De plus, les plants inoculés avaient une plus grande biomasse et prélevé davantage de phosphore que les semis non mycorhizés. L'inoculation par $P$. tinctorius et $S$. granulatus s'est traduite par des taux de photosynthèse de 1.87 et $1.85 \mathrm{mg}$ $\mathrm{CO}_{2} \cdot \mathrm{dm}^{-2} \cdot \mathrm{h}^{-1}$, respectivement ce qui est significativement plus élevé que celui des plants non mycorhizés $\left(1.41 \mathrm{mg} \mathrm{CO}_{2} \cdot \mathrm{dm}^{-2} \mathrm{~h}^{-1}\right)$. Bien que l'augmentation de croissance des semis mycorhizes soit associée à une augmentation de la photosynthèse, l'importance de cette réponse varie selon les conditions spécifiques d'irradiance et de fertilisation azotée. Ces résultats soulignent l'importance des interactions entre l'irradiance, la fertilisation azotée, et le développement des mycorhizes dans la croissance de semis en contenants.
Burk, T.E., N.D. Nelson, and J.G. Isebrands. 1983. Crown architecture of short-rotation, intensively cultured Populus. III. A model of first-order branch architecture. Can. J. For. Res. 13: 1107-1116.

A model was developed to describe the first-order branch architecture of Populus clones grown under short-rotation, intensive culture. Four basic model components described branch location along the tree bole, orientation of the branch in the plane in which it arises, taper of the branch, and the relation between leaf surface area supported by the branch and branch size. Branch arrangement along the tree bole was found to be symmetric for portions of the bole containing branches. Branch orientation was well described by assuming curvature to be constant, and branch taper was successfully modeled using a simple power function. Branch surface area was determined to be the most appropriate predictor of leaf surface area supported by the branch. Combining the four model components in a computer program allows an analysis of the dynamics of Populus crowns not previously possible.

$$
\text { * * * * * }
$$

Les auteurs ont mis au point un modèle mathématique pour décrire l'architecture des branches de premier ordre des clones de Populus, en culture intensive de courte révolution. Quatre constituants de base du modèle décrivent l'emplacement de la branche le long du tronc, l'orientation du plan où elle développe, son défilement, et la relation entre l'aire de surface des feuilles supportées par la branche et la taille de la branche. On a trouvé que l'arrangement des branches le long de la tige est symétrique pour la portion de la tige portant des branches. L'orientation d'une branche est bien décrite en assumant une courbature constante, et le défilement est bien prédit par un modèle de puissance simple. L'aire de surface d'une branche s'avère être le meilleur prédicteur de la surface foliaire portée par cette branche. La combinaison des quatre composantes du modèle dans un programme informatique permet une analyse de la dynamique des cimes de Populus qu'il n'était pas possible de réaliser antérieurement.

Hamilton, D.A., Jr., and J.E. Brickell. 1983. Modeling methods for a two-state system with continuous responses. Can. J. For. Res. 13: 1117-1121

A probabilistic two-step method of analysis is described that overcomes the problems associated with using a single model to analyze data drawn from a two-state system. The two steps of the analysis are (i) to determine the probability that an observation with given characteristics falls in each of the two states of the system and (ii) to estimate the resonse of the dependent variable in each of the two states as a function of characteristics of observations. Estimating cull volume in standing trees provides an example. This analysis results in two component models that more closely describe the process of interest than is possible with any single model. Statistically sound approximations to confidence intervals and tests of hypotheses for the parameters of each of the component models may be computed.

Une méthode probabilistique d'analyse à deux étapes qui surmonte les problèmes associés avec l'usage d'un modèle unique pour analyser les données tirées d'un système à deux stades est décrite. Les deux étapes d'analyse sont (i) déterminer la probabilité qu'une observation avec des caractéristiques données appartienne à l'un et à l'autre des deux stades du système et (ii) estimer la réponse de la variable dépendante dans chacun des deux stades en fonction des caractéristiques des observations. Une estimation du volume des arbres sur pied fournit un exemple. Cette analyse fournit des modèles à deux composantes qui décrivent plus fidèlement le comportement de l'intérêt qu'un modèle unique. Des approximations statistiquement robustes des intervalles de confiance et des tests d'hypothèse pour les paramètres de chacune des composantes des modèles peuvent être calculées par ordinateur. 
Steinhoff, R.J., D.G. Joyce, and L. Fins. 1983. Isozyme variation in Pinus monticola. Can. J. For. Res. 13: 1122-1132.

Seeds from 28 stands representing most of the range of $P$ inus monticola Dougl. were analyzed for electrophoretically demonstrable variation in 10 proteins encoded by 12 genetic loci. On the average, $65 \%$ of the loci per stand were polymorphic, and expected heterozygosity of offspring was $18 \%$. The populations could be assigned to two geographic groups, a broad northern one and a rather restricted southern one. The southern group consisted of populations from the Sierra Nevada and southern Cascade Mountains in northern California and from the Warner Mountains in south-central Oregon. These southern populations were similar to each other but all differed from those of the northern group in allelic frequency patterns for several isoenzymes. Across the northern part of the species' distribution (British Columbia, Washington, northern Oregon, Idaho, and Montana) differences among stands were minor and essentially random. Collections from stands in the central and southern Oregon Cascades and the Siskiyou Mountains of northwestern California were more nearly like the northern stands but exhibited some characteristics indicative of a transition area between the Sierra and northern types.

Les graines de 28 peuplements recouvrant la presque totalité de l'aire de distribution de Pinus monticola Dougl. sont analysées en fonction de la variation observable de 10 protéines codées par 12 locus génétiques. En moyenne, $65 \%$ des locus par peuplement sont polymorphiques et la proportion attendue de descendants hétérozygotes est de 18\%. Les peuplements peuvent être classés en deux groupes géographiques: un large groupe septentrional et un groupe méridional plutôt restreint. Le groupe méridional se compose des populations de la Sierre Nevada et du sud des montagnes Cascade en Californie du Nord, et des montagnes Warner du centre-sud de l'Oregon. Les patrons de fréquence allélique de plusieurs isoenzymes des populations méridionales se ressemblent mais diffèrent des patrons des populations du groupe septentrional. Dans la partie nord de l'aire de distribution de l'espèce (Colombie Britannique, Washington, nord de I'Oregon, Idaho et Montana), les différences entre peuplements sont mineures et fortuites. Les graines des peuplements du centre et du sud des "Oregon Cascades" et des montagnes Siskiyou du nord-ouest de la Californie ressemblent plutôt à celles des peuplements septentrionaux mais possèdent quelques caractéristiques d'une aire de transition entre la Sierra et les peuplements septentrionaux.

Fowler, D.P., and Y.S. Park. 1983. Population studies of white spruce. I. Effects of self-pollination. Can. J. For. Res. 13 1133-1138.

The effects of self-pollination in white spruce, Picea glauca (Moench) Voss, were examined in 20 trees in three populations. The most drastic effect is the increased frequency of empty seeds which averages over $90 \%$, and is 5 to 22 times higher than that from comparable cross-pollinations. The average numbers of embryonic lethal equivalents, although highly variable for individual trees, averaged 8.0,9.1, and 12.9 for the three populations. Self-pollination also resulted in slightly lower germination and reduced survival. The total number of lethal equivalents affecting seed yield, germination, and survival to age 17 years is estimated as 12.6. The effect of selfing on growth becomes evident at age 2 years and increases to age 17 years when seedlings from selfpollinations averaged $44.5 \%$ shorter and $63.7 \%$ smaller diameter than seedlings from unrelated matings.

On a étudié les effets de l'autopollinisation de l'épinette blanche, chez 20 arbres choisis dans trois populations. L'effet le plus spectaculaire est le taux de graines vides, qui s'élève en moyenne à plus de $90 \%$ et est de 5 à 22 fois celui qui résulte de la pollinisation croisée dans des conditions comparables. Même s'il était très variable d'un arbre à l'autre, le nombre moyen d'équivalents létaux embryonnaires s'élevait à $8,0,9,1$ et 12,9 chez les trois populations. L'autopollinisation a aussi provoqué une germination légèrement inférieure et une survie réduite. Le nombre total d'équivalents létaux influant sur le rendement en graines, la germination et la survie jusqu'à l'âge de 17 ans est estimé à 12,6. L'effet de l'autopollinisation sur la croissance devient évident à 2 ans et croît jusqu'à 17 ans, lorsque les semis qui résultent de l'autopollinisation sont en moyenne plus courts de $44,5 \%$ et plus petits en diamètre de $63,7 \%$ que les semis provenant de croisements d'arbres non apparentés.

Tisserat, N., and J.E. Kuntz. 1983. Dispersal gradients of conidia of the butternut canker fungus in a forest during rain. Can. J. For. Res. 13: 1139-1144.

Dispersal gradients of conidia of Sirococcus clavigignentijuglandacearum Nair, Kostichka, and Kuntz, the causal agent of butternut canker, were studied in the forest for various rainfall dates. During rain, large numbers of conidia from branch cankers were carried in runoff water down the tree trunks of butternut (Juglans cinerea L.), causing infections that resulted in trunk cankers. Conidia also were dispersed in small droplets or aerosols and disseminated up to $40 \mathrm{~m}$ from a cankered tree during rainfall. Concentrations of conidia in the air decreased exponentially with increasing distances from the inoculum source. Dispersal gradients were influenced by stand composition and (or) size of the inoculum source, with steeper gradients associated with a dense forest canopy and a small area source of inoculum. Weather conditions, excluding the necessity for rain, had little influence in altering dispersal gradients within the same stand for different rainfall dates.

Au cours de journées avec précipitation, on a étudié en forêt les variations de la dispersion de conidies du Sirococcus clavigignenti-juglandacearum Nair, Kostichka et Kuntz, l'agent incitatif du chancre du noyer cendré. Pendant la pluie, à partir de chancres de branche, de grandes quantités de conidies ont été emportées dans l'eau de ruissellement le long des troncs de noyer cendré (Juglans cinerea L.) générant des infections qui ont provoqué des chancres de tronc. Durant une précipitation, des conidies se sont aussi dispersées dans de fines gouttelettes ou dans la buée pour être disséminées jusqu'à $40 \mathrm{~m}$ d'un arbre chancreux. Les concentrations de conidies dans l'air ont diminué de façon exponentielle en rapport avec l'accroissement de la distance de la source de l'inoculum. La composition du peuplement et (ou) la dimension de la source d'inoculum ont influencé les niveaux de variation de la dispersion, les changements les plus prononcés s'observant sous une forêt à couvert dense et avec une source d'inoculum provenant d'une surface réduite. $\AA$ part le besoin essentiel de pluie, les conditions climatiques n'ont guère modifié les niveaux de dispersion des conidies à l'intérieur d'un même pueplement lors de différentes journées avec précipitation.

Grossnickle, S.C., and C.P.P. Reid. 1983. Ectomycorrhiza formation and root development patterns of conifer seedlings on a high-elevation mine site. Can. J. For. Res. 13: 1145-1158.

Three conifer species, Pinus contorta Dougl., Pinus flexilis James, and Picea engelmannii Parry ex Engelm. were inoculated with the ectomycorrhizal fungi Pisolithus tinctorius (Pers.) Coker \& Couch. Suillus granulatus (L. ex Fr.) Kuntze, and Cenococcum geophilum $\mathrm{Fr}$. These, plus noninoculated seedlings were planted under two fertilization treatments and grown for 5 years on a high-elevation $(3200 \mathrm{~m})$ mine site. One-year-old $P$. contorta and $P$. engelmannii seedlings inoculated with the ectomycorrhizal fungi $P$. tinctorius and $S$. granulatus were planted under two fertilization and three water conservation treatments, and grown on a high-elevation mine site for 1 year. After one growing season, mycorrhizae formed by $P$. tinctorius and $S$. granulatus were stili visible on $P$. contorta seedlings root systems. However, after five growing seasons, $P$. tinctorius and $C$. geophilum were not visible on the roots of $P$. contorta and $P$. flexilis seedlings, although mycorrhizae formed by $S$. granulatus appeared to be present. Few mycorrhizae were observed on the root systems of 1 - or 5-yearold $P$. engelmannii seedlings. Root system development of 1 - and 5 -year-old $P$. contorta and $P$. engelmannii seedlings was dramatically reduced by the sewage sludge and wood-chips fertilization 
treatment, but fertilization treatments had no apparent effects on root system development of 5-year-old $P$. flexilis.

$$
\text { * } \quad \text { * } \quad \text { * }
$$

Trois espèces de conifères, le Pinus contorta Dougl., le Pinus flexilis James, et le Picea engelmannii Parry ex Engelm., ont été inoculées avec les champignons ectomycorhiziens suivants: Pisolithus tinctorius (Pers.) Coker \& Couch, Suillus granulatus (L. ex Fr.) Kuntze, et Cenococcum geophilum Fr. Ces plants ainsi que des sujets témoins non inoculés ont été plantés sur un site minier à haute élévation $(3200 \mathrm{~m})$; les plantations ont été soumises à deux modes de fertilisation et ont été suivies pendant cinq ans. De plus, des plants de $P$. contorta et $P$. engelmannii inoculés avec les champignons ectomycorhiziens $P$. tinctorius et $S$. granulatus ont été plantés sous deux régimes de fertilisation et trois traitements de conservation de l'eau; ils ont été également plantés sur le site minier à haute altitude, mais suivis pendant une seule année. Après une saison de croissance, les mycorhizes formées par le $P$. tinctorius et le $S$. granulatus étaient encore visibles sur les systèmes racinaires du $P$. contorta. Cependant après cinq saisons de croissance, le $P$. tinctorius et le $C$. geophilum n'étaient plus visibles sur les racines ni du $P$. contorta ni du $P$. flexilis bien que les mycorhizes du $S$. granulatus semblaient encore présentes. Peu de mycorhizes ont pu être observées sur les systèmes racinaires des plantules du $P$. engelmannii après 1 et 5 années. Le développement des systèmes racinaires de $P$. contorta et des $P$. engelmannii a été sévèrement limité par les traitements avec des boues d'égout ou avec des copeaux de bois alors que la fertilisation ne semble pas avoir affecté le développement des systèmes racinaires de $P$. flexilis après 5 années

Stanton, B.J., and D.S. Canavera. 1983. Phenotypic selection in Betula papyrifera. Can. J. For Res. 13: 1159-1163

Phenotypically superior trees of Betula papyrifera Marsh. were identified on the basis of their breast height stem diameters in two even-aged stands in western Maine. The growth superiority of each of the candidate trees was evaluated further using one of three different selection methods. Two methods were based on mean annual volume increment and differed in regard to their use of comparison trees. Selected trees were those which grew the most volume throughout the life of the stand. In the third procedure, periodic basal area increment was compared with the estimated basal area increment using an equation incorporating crown surface area as an independent variable. Trees rated as most superior were those which produced the largest increment in relation to crown size. Open-pollinated progenies of selected and control trees were evaluated for height growth and stem diameter in a greenhouse trial. Although significant differences in height existed among the selection methods, no one method was successful in identifying trees whose progenies, as a group, were significantly taller than the average of the control progenies.

Les auteurs ont identifié phénotypiquement des arbres-plus de Betula papyrifera Marsh. relativement à leur diamètre, dans deux peuplements équiennes dans la partie occidentale du Maine. La croissance supérieure des arbres sélectionnés a été évaluée par la suite, en utilisant une de trois méthodes de sélection. Deux de ces méthodes étaient basées sur l'accroissement annuel moyen en volume, comparé aux arbres retenus. Les arbres sélectionnés sont ceux qui ont produit le plus grand volume durant toute la vie du peuplement. Dans la troisième méthode utilisée, les auteurs ont comparé l'accroissement périodique de la surface terrière avec l'accroissement estimé de celle-ci au moyen d'une équation englobant la superficie de la cime considérée comme variable indépendante. Ainsi, les arbres classés supérieurs étaient ceux qui ont produit le plus fort accroissement en relation avec l'importance de la cime. Des descendances issues de pollinisation libre tant d'arbres sélectionnés que de tiges-contrôles ont été évaluées dans un essai en serre, suivant la croissance en hauteur et le diamètre de la tige. Bien que les auteurs aient enregistrée des différences significatives dans la hauteur parmi les méthodes sélectives, aucune méthode ne s'est avérée efficace pour identifier les arbres dont les descendances, en tant que population, étaient significativement plus grandes que la moyenne des descendances des tiges-contrôles.
Strong, W.L. and G.H. La Roi. 1983. Root-system morphology of common boreal forest trees in Alberta, Canada. Can. J. For. Res. 13: 1164-1173.

Twenty-four specimens of six boreal tree species were excavated: eight Pinus banksiana Lamb., five Populus tremuloides Michx., four Picea glauca (Moench) Voss, three Picea mariana (Mill). B.S.P., two A bies balsamea (L.) Mills., and two Larix laricina (Du Roi) K. Koch. Root systems were described, and percent biomass determined for above- and below-ground components for half these specimens. Tree ages ranged from 3 to 120 years. Horizontally spreading lateral roots dominated the root systems of all species and occurred within $3-15 \mathrm{~cm}$ of the ground surface. Nutrient and moisture absorption appear to be the principal functions of lateral roots. Maximum vertical root growth occurred near the tree stump as: tap-, heart, sinker, and oblique lateral roots. Vertical root morphology is influenced by site conditions. In addition to providing mechanical support, sinker and taproots may be important adaptations for deep-water utilization on xeric sites. Our data suggest that roots may be important in boreal succession processes through two related mechanisms: (i) nutrient and water deprivation occurring through preemptive growth of tree roots from climax species over roots of seral species, and through interception by mosses; and (ii) niche partitioning occurring below ground between seral and climax, and among climax tree species, by vertical separation of the root systems.

Vingt-quatre spécimens de six essences forestières ont été déracinés en vue de décrire leur système racinaire, soit huit $P$ inus banksiana Lamb., cinq Populus tremuloides Michx., quatre Picea glauca (Moench) Voss, trois Picea mariana (Mill.) B.S.P., deux Abies balsamea (L.) Mills, et deux Larix laricina (Du Roi) K. Koch. Pour la moitié des spécimens, on a mesuré le pourcentage de biomasse aérienne et de biomasse hypogée. L'âge des arbres variait de 3 à 120 ans. Le système racinaire de toutes les espèces était formé surtout de racines latérales réparties horizontalement dans les premiers $3-15 \mathrm{~cm}$ du sol. L'absorption d'eau et d'éléments nutritifs semble être la principale fonction des racines latérales. La croissance verticale des racines était surtout marquée à proximité de la souche, sous forme de pivot principal, de pivots secondaires et de racines latérales obliques. En plus de constituer l'ancrage, les racines pivotantes peuvent constituer des moyens d'adaptation pour le prélèvement d'eau en profondeur, dans les stations xériques. Les présentes observations suggèrent que le système racinaire peut avoir un rôle important dans les processus de succession, par le biais de deux mécanismes interreliés: (i) les teneurs en eau et en éléments nutritifs seraient réduites par une croissance préemptive des racines des espèces climaciques par rapport aux espèces sériales, et par suite de l'interception en surface par les mousses; et (ii) une répartition en niche se produit sous la surface du sol entre espèces sériales et espèces climaciques, et entre les espèces climaciques ellesmêmes, par suite de la séparation verticale des systèmes racinaires.

Nautiyal, J.C., and B.K. Singh. 1983. Using derived demand techniques to estimate Ontario roundwood demand. Can. J. For. Res. 13: 1174-1184.

Derived demand for roundwood created by the three major forest-products industries in Ontario from 1952 to 1980 was estimated from the production functions of the industries. The CobbDouglas function represents the lumber and the veneer and plywood industries, and the constant elasticity of substitution (CES) function represents the pulp and paper industry. In all three industries, the derived demand for roundwood is price inelastic. A theorem that the sum of partial price elasticities of derived demand when output of the final product is held constant is equal to zero has been proved. Demand by the lumber industry showed regular fluctuations throughout the 29-year period of study, while that by the other two industries rose steadily except for a few slumps.

En se servant de fonctions de production propres à chacun des trois principaux types d'industrie forestière en Ontario, on a évalué la demande dérivée pour des bois ronds telle que générée 
par ces industries de 1952 à 1980. La fonction Cobb-Douglas s'applique à l'industrie du bois de sciage et à celle du déroulage et des contreplaqués, la fonction CES, à l'industrie des pâtes et papiers. Dans les trois types d'industrie, la demande dérivée pour des bois ronds est sujette à un prix uniforme. On a démontré un théorème à l'effet que, quand le volume du produit final est maintenu constant, la somme des variations partielles du prix de la demande dérivée est égale à zéro. Au sein de l'industrie du bois de sciage, la demande a fait l'objet de fluctuations régulières durant la période de l'étude (29 ans) alors que chez les deux autres types d'industrie, elle s'est accrue constamment, à l'exception de quelques défaillances.

Fowler, G.W. 1983. Accuracy of sequential sampling plans on Wald's sequential probability ratio test. Can. J. For. Res. 13: 1197-1203.

Monte Carlo operating characteristic $(\mathrm{OC})$ and average sample number (ASN) functions were compared with Wald's OC and ASN equations for sequential sampling plans based on Wald's sequential probability ratio test (SPRT) using the binomial, negative binomial, normal, and Poisson distributions. This comparison showed that the errors inherent in Wald's equations as a result of "overshooting" the decision boundaries of the SPRT can be large. Relative errors increased for the $\mathrm{OC}$ and $\mathrm{ASN}$ equations as the difference between the null $\left(\theta_{0}\right)$ and alternative $\left(\theta_{1}\right)$ test parameter values increased. Relative errors also increased for the ASN equation as the probabilities of type I $(\alpha)$ and type II $(\beta)$ errors increased. For discrete distributions, the relative errors also increased as $\theta_{0}$ increased with $\theta_{1} / \theta_{0}$ fixed. Wald's equations, in general, overestimate the true error probabilities and underestimate the true ASN. For the values of $\theta_{0}, \theta_{1}, \alpha$, and $\beta$ used in many sequential sampling plans in forestry. Wald's equations may not be adequate. For those cases where the errors in Wald's equations are important compared with the other errors associated with the sampling plan, two alternative Monte Carlo OC and ASN functions are proposed.

Les fonctions opérations caractéristiques (OC) et nombre moyen d'échantillons (ASN) de Monte Carlo, ont été comparées avec les équations OC et ASN de Wald pour des plans d'échantilIonnage séquentiel à partir du test quotient de probabilité séquentielle de Wald (SPRT) en utilisant les distributions binomiale, binomiale négative, normale et Poisson. Cette comparaison montre que les erreurs inhérentes aux équations de Wald dues au dépassement des limites de décision du SPRT, peuvent être grandes. Les erreurs relatives augmentent pour les équations $\mathrm{OC}$ et ASN comme la différence entre les valeurs des paramètres augmentent dans le test des hypothèses nulles $\left(\theta_{0}\right)$ et alternative $\left(\theta_{1}\right)$. Les erreurs relatives augmentent aussi pour l'équation ASN comme les probabilités des erreurs de type I $(\alpha)$ et de type II $(\beta)$ augmentent. Pour les distributions discrètes, les erreurs relatives augmentent aussi comme $\theta_{0}$ augmente $\operatorname{avec} \theta_{1} / \theta_{0}$ fixé. Les équations de Wald, en général, surestiment les vraies probabilités d'erreur et sous-estime la vraie ASN. Pour les valeurs de $\theta_{0}, \theta_{1}, \alpha$, et $\beta$ utilisées dans plusieurs plans d'échantillonnage séquentiel en foresterie, les équations de Wald ne sont pas adéquates. Pour les cas où les erreurs dans les équations de Wald sont importantes, comparativement aux autres erreurs associées au plan d'échantillonnage, nous proposons comme alternative les fonctions de Monte Carlo OC et ASN.

Durzan, D.J. 1983. Metabolism of tritiated water during imbibition and germination of jack pine seeds. Can. J. For. Res. 13: 1204-1218.

Tritiated water was used to study the metabolic fate of water in seeds of jack pine (Pinus banksiana Lamb.) during imbibition and under the influence of a reversible phytochrome reaction. Since levels of tritium greater than $15 \mathrm{mCi} \cdot \mathrm{mL}$ water ${ }^{-1} \cdot \mathrm{g}$ seeds $^{-1}$ inhibited germination in more than $50 \%$ of the seeds, all studies were performed well below this level. During imbibition over $80 \%$ of the total covalently bound radioactivity derived from tritiated water resided in glucose and fructose. Enzymes involved in gluconeogenesis viz. fructose 1,6-bisphosphatase and glycolysis viz. phosphoglucose isomerase, in these fat-storing seeds were pos- tulated contributing to the recovery of covalent tritium from glucose especially in red light. Brief exposures of seeds to red and far-red light during imbibition affected mainly the level and distribution of radioactivity in sugars and to a lesser extend the major components of the free amino acid pool, viz. alanine, glutamic acid, and amides. Under cool white light, the highest specific activities were seen with aspartate and $\gamma$-aminobutyrate. In germinating seedlings, the recovery of tritium, almost entirely from the deoxyribose moiety of newly synthesized DNA, pointed to the importance of (i) light-mediated ribonucleotide reductases for DNA synthesis, (ii) enzymes of the pentose phosphate shunt during imbibition, and (iii) structural integrity of developing subcellular organelles in embryonic cells during imbibition.

L'auteur a utilisé l'eau tritiée pour étudier le cheminement métabolique de l'eau pendant son absorption dans les graines de Pinus banksiana Lamb. sous l'influence d'une réaction phytochrome réversible. Toutes les expériences furent effectuées avec des taux de tritium inférieurs à $1515 \mathrm{mCi} \cdot \mathrm{mL} \mathrm{eau}^{-1} \cdot \mathrm{g}_{\text {graines }}{ }^{-1}$ cette valeur inhibant la germination de plus de $50 \%$ des semences. Pendant l'absorption, plus de $80 \%$ de la radioactivité totale dérivée de l'eau tritiée, fut retrouvée sous forme de glucose et de fructose. Dans les semences riches en réserves de graisse, les enzymes impliquées dans la gluconéogénèse (fructose 1,6diphosphate) et dans la glycolyse (phosphoglucose isomérase) pourraient contribuer à la récupération du tritium covalent du glucose, particulièrement en présence de lumière rouge. De courtes expositions des semences à la lumière rouge et rouge éloignée pendant l'absorption affectent principalement le niveau et la distribution de la radioactivité dans les sucres et, à un moindre degré, les composants majeurs du pool d'acides aminés libres comme l'alanine, l'acide glutamique et les amides. Sous une lumière blanche, la plus haute activité spécifique a été observée avec l'aspartate et la $\gamma$-aminobutyrate. Dans les semences en germination, le fait que la récupération du tritium vienne principalement du désoxyribose de l'ADN nouvellement synthétisé démontre l'importance (i) de la ribonucléotide réductase en présence de lumière pour la synthèse de I'ADN, (ii) des enzymes du sentier des pentoses phosphates pendant l'absorption, (iii) de l'intégrité des structures subcellulaires en croissance dans les cellules embryonnaires pendant l'absorption.

Imper, D.K., and D.B. Zobel. 1983. Soils and foliar nutrient analysis of Chamaecyparis lawsoniana and Thuja plicata in southwestern Oregon. Can. J. For. Res. 13: 1219-1227

Surface mineral soil and foliage associated with Chamaecyparis lawsoniana (A. Murr.) Parl. and Thuja plicata Donn ex D. Don were sampled at six sites in southwestern Oregon. Total soil nitrogen concentrations ranged from 0.08 to $0.37 \%$. Percentage exchangeable concentrations of other soil nutrients were 0.0002 $0.0020 \mathrm{P}, 0.014-0.224 \mathrm{Ca}, 0.002-0.018 \mathrm{~K}$, and $0.002-0.023 \mathrm{Mg}$ Foliage of Chamaecyparis contained $0.9-1.9 \% \mathrm{~N}, 0.11-0.23 \% \mathrm{P}$ $0.8-1.9 \% \mathrm{Ca}, 0.67-1.20 \% \mathrm{~K}$, and $0.11-0.26 \% \mathrm{Mg}$. Foliage of Thuja contained $0.9-1.6 \% \mathrm{~N}, 0.12-0.24 \% \mathrm{P}, 1.1-2.0 \% \mathrm{Ca}, 0.52-0.95 \% \mathrm{~K}$ and $0.06-0.23 \% \mathrm{Mg}$. Overall, foliage of Chamaecyparis contained significantly higher concentrations of $\mathrm{K}$, and tended to have lower Ca:Mg ratios than that of Thuja. Concentrations of soil nutrients showed no obvious relation to species occurrence on a studywide basis. Within sites where the two species grew together, however, Thuja was associated with higher soil $\mathrm{Ca}: \mathrm{Mg}$ ratios and foliar $\mathrm{Ca}$, and Chamaecyparis was associated with higher levels of soil $\mathrm{K}$ and foliar $\mathrm{N}$. Foliar nutrient concentrations showed little relation to concentrations in soil, although low soil $\mathrm{Ca}, \mathrm{P}$, and $\mathrm{Mg}$ concentrations were reflected in foliage at some sites. Soils in the study area have higher $\mathrm{Ca}: \mathrm{Mg}$ ratios and more available $\mathrm{N}$ than soils over much of Chamaecyparis' range. Given the apparent nutritional requirements of Thuja, it seems unlikely that it will significantly replace Chamaecyparis killed by root rot.

Les auteurs ont échantillonné le sol minéral de surface et le feuillage de Chamaecyparis lawsoniana (A. Murr.) Parl. et de Thuja plicata Donn ex D. Don dans six stations du sud-est de l'Orégon. Les concentrations en azote total du sol étaient de 0,08 à $0,37 \%$; celles de $\mathrm{P}$ disponible et des éléments échangeables 
s'élevaient à $0,0002-0,0020 \mathrm{P}, 0,014-0,224 \mathrm{Ca}, 0,002-0,018 \mathrm{~K}$, et $0,002-0,023 \mathrm{Mg}$. Le feuillage de Chamaecyparis renfermait 0,9$1,9 \%$ N, $0,11-0,23 \%$ P, $0,8-1,9 \% \mathrm{Ca}, 0,67-1,20 \% \mathrm{~K}$, et $0,11-0,26 \%$ $\mathrm{Mg}$; celui de Thuja renfermait $0,9-1,6 \% \mathrm{~N}, 0,12-0,24 \% \mathrm{P}, 1,1-2,0 \%$ $\mathrm{Ca}, 0,52-0,95 \% \mathrm{~K}$, et $0,06-0,23 \% \mathrm{Mg}$. Dans l'ensemble, le feuillage de Chamaecyparis était significativement plus riche en potassium que celui de Thuja, mais son ratio $\mathrm{Ca}: \mathrm{Mg}$ était généralement plus faible. En considérant l'ensemble des stations, la distribution des espèces ne semble pas être liée aux concentrations des éléments du sol. Toutefois, à l'intérieur des stations où croissent les deux espèces, Thuja est associé à un ratio $\mathrm{Ca}: \mathrm{Mg}$ du sol plus élevé et à une concentration foliaire de Ca plus grande, tandis que Chamaecyparis est associé à un plus haut niveau en $\mathrm{K}$ du sol, et son feuillage a une teneur plus élevée en azote. Peu de relations ont été observées entre les teneurs en éléments du feuillage et les concentrations dans le sol, si ce n'est que les faibles concentrations en $\mathrm{Ca}, \mathrm{P}$ et $\mathrm{Mg}$ du sol se traduisaient au niveau des concentrations foliaires dans certaines stations. Les sols de la région étudiée ont des rapports Ca:Mg plus élevés et renferment plus d'azote disponible que les sols en général de l'aire de distribution de Chamaecyparis. Etant donné les besoins apparents en éléments de Thuja, il est peu probable que cette espèce puisse remplacer d'une façon significative le Chamaecyparis tué par la pourriture des racines.

Luken, J.O., and R.W. Fonda. 1983. Nitrogen accumulation in a chronosequence of red alder communities along the Hoh River, Olympic National Park, Washington, Can. J. For. Res. 13: $1228-1237$.

Alnus rubra Bong. dominates the first $65-80$ years of a sere that is initiated naturally on the terraces of the Hoh River. Stands of 14 , 24 , and 65 years were studied to determine to what extend the Alnus stage enriched the nitrogen inventory of the site. Bare sandbars deposited by the river had a mean of $783 \mathrm{~kg} / \mathrm{ha}$ nitrogen. Alnus communities caused an increase in the nitrogen inventory so that, by 65 years, total community nitrogen was 4659 $\mathrm{kg} / \mathrm{ha}$, soils held $3594 \mathrm{~kg} / \mathrm{ha} \mathrm{N}$ in the upper $45 \mathrm{~cm}$, and A/nus trees held $942 \mathrm{~kg} / \mathrm{ha} \mathrm{N}$. The nitrogen contents of the soil, Alnus wood, bark, and branches, grasses, total aboveground biomass, total belowground biomass, and sticks less than $1 \mathrm{~cm}$ diameter all showed significant increases from 14 to 65 years. The $A$. rubra stage is an important link in the nutrient inventory between unvegetated, recently deposited sandbars and the climax coniferous forests dominated by Tsuga heterophylla (Raf.) Sarg. and Picea sitchensis (Bong.) Carr.

$$
\text { * * } * * *
$$

Alnus rubra Bong, domine les premières $65-80$ années d'une sère naturelle de végétation sur les terrasses de la Rivière Hoh. Les auteurs ont étudié des peuplements âgés de 14,24 et 65 ans, en vue de déterminer à quel point l'aulne contribue à enrichir le capital d'azote de la station. Les barres sableuses dénudées, déposées par la rivière, renfermaient en moyenne $783 \mathrm{~kg} \mathrm{~N} / \mathrm{ha}$.
Les communautés d'Alnus ont entraîné une augmentation du capital d'azote tel que, à 65 ans, le stock d'azote du système s'élevait à $4659 \mathrm{~kg} / \mathrm{ha}$, réparti comme suit: $3594 \mathrm{~kg} / \mathrm{ha} \mathrm{N}$ dans les premiers $45 \mathrm{~cm}$ du sol et $942 \mathrm{~kg} / \mathrm{ha} \mathrm{N}$ dans la biomasse d'Alnus. Les quantités d'azote accumulé dans le sol, dans le bois, l'écorce et les branches d'Alnus, dans la végétation herbacée et dans la biomasse aérienne totale ont toutes montré une augmentation entre 14 et 65 ans. Le stade d'A. rubra représente une étape essentielle dans la constitution d'un capital d'éléments, entre le stade des sables récents, non couverts de végétation et celui des forêts climax de conifères dominées par Tsuga heterophylla (Raf.) Sarg. et Picea sitchensis (Bong.) Carr.

Wingfield, M.J. 1983. Association of Verticicladiella procera and Leptographium terrebrantis with insects in the Lake States. Can. J. For. Res. 13: 1238-1245.

Verticicladiella procera Kendrick was isolated from damage associated with Dendroctonus valens Lec., Hylobius radicis Buch., Hylobius rhizophagus M.B.W., Hylobius pales (Herbst), and Pachylobius picivorus (Germ.) on pines in Minnesota, Wisconsin, and Michigan. The fungus was also isolated from surfacesterilized adult $D$. valens. $H$. radicis, $H$. pales, and $P$. picivorus. Leptographium terrebrantis Barras and Perry was isolated from the galleries of $D$. valens on trees stressed by fire, flooding, windthrow, and tissue attacked by $H$. radicis or $H$. rhizophagus. Verticicladiella procera was not pathogenic on white pine seedlings whereas L. terrebrantis killed $70 \%$ of seedlings inoculated. Verticicladiella procera appears to be weakly pathogenic and is associated with primary ( $H$. radicis and $H$. rhizophagus) and secondary ( $P$. picivorus, $D$. valens, $H$. pales) forest insects in the north central United States. Leptographium terrebrantis was more virulent than $\checkmark$. procera and was associated with a secondary bark beetle which commonly attacks stressed trees.

$$
\text { * * * * * }
$$

Verticicladiella procera Kendrick à été isolé des pins en assuciation avec Dendroctonus valens Lec., Hylobius radicis Buch., Hylobius rhizophagus M.B.W., Hylobius pales (Herbst), et PachyIobius picivorus (Germ.) au Minnesota, Wisconsin et Michigan. Ce champignon a aussi été récupéré sur des spécimens adultes de $D$. valens. $H$. radicis, $H$. pales, et $P$. picivorus après une stérilisation superficielle. Leptographium terrebrantis Barras et Perry a été isolé dans les galeries de $D$. valens sur des arbres affectés par le feu, les innondations, les chablis et dans les tissus attaqués par $H$. radicis ou $H$. rhizophagus. Innoculés sur des semis de pin blanc, $V$. procera n'était pas pathogène alors que $L$. terrebrantis a causé $70 \%$ de mortalité. Verticicladiella procera semble être un pathogène peu agressif associé aux insectes primaires $(H$. radicis et $H$. rhizophagus) et secondaires ( $P$. picivorus, $D$. valens, $H$. pales) du centre-nord des États-Unis. Leptographium terrebrantis est plus virulent que $\mathrm{V}$. procera et est associé à un insecte secondaire qui se développe dans l'écorce des arbres affaiblis. 